\title{
JENS-MARTIN ERIKSEN
}

\section{uddrag fra Vinter ved daggry, beretning}

Den næste dag vågnede jeg lidt før de andre. Der var endnu helt stille der på sovesalen, kun nogle svage lyde ude fra køkkenet, som jeg med besvær kunne ane, når jeg lå og koncentrerede mig. Ellers ingenting. Folk, der vendte sig, ligesom de allerede dér i søvnen forberedte sig på det ubehagelige, som vi allesammen alt for godt vidste, nu endelig ville indtræffe. Nærmest som om kroppene endnu før de er vækket, allerede instinktivt kvier sig ved den dag, som de skal stå op til. Vender og drejer sig i ubehag, eller maser og lukker sig ned i sengen for at beholde den uskyldighed, som de endnu har. Selv vovede jeg bare at åbne øjnene lidt, og så lukke dem igen. Men jeg rørte ikke på mig af angst for at nogen af de andre skulle se, at jeg allerede var vågen, og så ville begynde at hviske noget til mig. Og når jeg lå der med lukkede øjne, så kunne jeg spørge mig selv, om det nu virkelig var idag, at det skulle være? Jeg gentog spørgsmålet for mig selv igen og igen, men kunne ikke sove ind på ny, og hver eneste gang, så blev jeg nødt til at svare, som sandt var. Ja, det skulle være idag. Gid jeg dog kunne sove, tænkte jeg, gid det hele blot var et langt og ubærligt mareridt, som kunne martre mig, riste mig og lære mig noget, så jeg måske kunne have handlet i tide. Jeg skulle gerne købe mig et mareridt for den dag, der nu forestod. Men hvor meget jeg end forsøgte, så kunne jeg ikke endnu engang leve mig ind i den illusion, at det blot var noget pinefuldt, som jeg forestillede mig. Jeg var vågen, og uigenkaldeligt på vej mod en ny dag. Jeg ved ikke. For at standse tiden, for at standse det daggry, som man er vågnet til, for at holde tankerne i ave, så begynder man at lege med ordene. Nærmest som for at begynde øjeblikket igen og igen, blot for at noget ikke skal nå ind i sit uigenkaldelige forløb, og den nye dag så at sige voldføre én. Som 
båret af en angst jo, ligesom drømmenes logik, der ikke nødvendigvis er liniære som tiden, men permanent kan standse før et traumatisk punkt af sandhed, før noget uafvendeligt, og så til stadighed mønstre nye begyndelser, repetitioner, uafladeligt indtil man befries af søvnen. Men for mig, der var det lyset jeg var bange for. Jeg ønskede mig bare et mørke, der kunne vare. "Så det er så den ny dag, så det er så den ny dag", blev jeg ved med at gentage $i$ en uendelighed der bag ved mine lukkede øjne, underligt imbecilt, nærmest som om jeg slet ikke fattede det. Men det var jo helt enkelt, for jeg selv havde indskrevet mig til militsen, tåbeligt, for blot at kunne slippe billigere, som det hed sig. Så tilforladeligt, som sådan noget kan lyde mange kilometer væk, på en tilfældig eftermiddag, hvor man har vrøvlet om hvordan det hele kan overståes. Så gør man det, går hen på mønstringskontoret, udfylder sine papirer, det hele er enkelt som at lægge et brev i postkassen. Og man tror gerne på det, for det er jo blevet almindeligt. Og så er der så lang tid til sådan en morgen der, som jeg lå der, imbecilt fremmumlende den der samme sætning igen og igen. Nærmest som at leve ubekymret og syndigt vel, og så pludselig stå over for en dommedag, hvor alt sådan skulle afgøres for én. Man kunne ikke rigtig med nogen god ret sige, at man ikke var advaret. $\mathrm{Og}$ så skrumper man ind der på sengen, til en lille foetus, ja intellektuelt helt ind i fosterstadiet, og ligger katatonisk og fremmumler sin undren over at dagen ja, den nu er ved at oprinde. Ikke sært; at den mærkværdige undren man kan opbyde, den er forbundet med lige dele lede ved sig selv og sin egen idiotiske færdighed til at gå blindt fremad med lukkede øjne. Og formildet med den bedøvelse, at vi så er mange, der går fremad, blinde og trofaste mod målet. Hvor er det dog ubegribeligt, men også på en måde sært desillusionerende, denne evne til at lægge sit liv og sin skæbne i andres hænder. Tænk sig, at man ikke skulle være mere bevendt, at den viden, som man måtte have indbildt sig, at man havde optaget efter alle slags år, at den, når det kom til én selv, skulle vise sig at være så helt igennem ubrugelig. Hvad havde man så egentlig lært? Hvad tjente det hele til? Hvilken forfængelighed lå der i hele min drøm om at læse, at studere? Og litteratur? Det eneste forsonende var vel, når alt kom- 
mer til alt, som jeg lå der og mumlede som en imbecil, at ingen af de andre, som søvnen endnu lagde en slags forsoningens udsættelse henover, at de ikke var i stand til at læse mine tanker.

Nå. Man ligger og ryster sig vågen, så at sige, mentalt, ved sådan et mantra. Og efterhånden, så går det jo op for én, at det er den virkelige dag, man er vågnet til. At alt det man frygter skal ske, det er dagsordenen for den dag, som er ved at gry. Og jeg begyndte frygtsomt at forestille mig, at jeg igen skulle blive sat af bussen sammen med Gamma eller en anden. Gerne Ludo, som jeg følte, jeg på sæt og vis kunne støtte mig til med en fælles uskyldighed. At vi gjorde holdt i Columbus, blev smidt ud på gaden der i solen, og så de ansigter fra folk på gaden, som ville stirre på os. Nu ikke mere med den uskyldige forfjamskelse, som dagen forinden. De ville helt præcist vide hvad vi var kommet for, de ville ikke frygte os som øvrighedspersoner, ligesom dagen forinden, og mere eller mindre blindt adlyde vore ordrer. For, når alt kom til alt, så var der jo ikke noget for dem at frygte før vi udløste de trusler for alvor, som vi havde med os. Det ville ikke mere være nok at råbe til dem, true dem med geværet, presse det ind $\mathrm{i}$ kroppen på dem, og bede dem forføje sig fra derfra hvor vi stod. De ville se på os, og de ville vide eksakt hvad vi tænkte, mere forskellige var vi jo ikke, dem og os. Jeg lå der og forestillede mig dette helvede, den der eksponering, og hvilken generthed, nej hvilken offentlig ydmygelse, den ville påføre mig. At jeg for alle mennesker, at jeg på en offentlig plads skulle udstille alt det der dyriske i mig, det aller mest hemmelige. Jeg ved ikke om man kan forstå det, nårjeg fortæller det? Men deter jo som at udstille en fuldstændig grotesk perversitet for almindelige, anstændige mennesker, helt uden varsel. Som at deltage i et, hvad ved jeg, et uhæmmet ekshibitionistisk, sodomitisk orgie, en eller anden burlesk og brutal cirkus. Bare at pånøde hèlt fremmede almindelige folk dette skamfulde syn. Sammenligningen kan rimeligvis lyde koket, men hvad skammen angår, så er den ikke desto mindre præcis. Jeg ved ikke. Skulle denne kvinde komme ud til mig igen, hende der fra det medicinske håndkøbsudsalg, og anklage mig for sine forsvundne sønner, sin forsvundne mand, og 
ikke bare brokke sig overfor mig, fordi jeg forstyrrede hendes forretning? Hvad ville jeg sige, hvordan ville jeg se hende i øjnene? Skulle jeg virkelig blive konfronteret med hende, med sådan et øjeblik, så måtte jeg tage min opgave på mig, for alvor, den her opgave med at skyde deres mænd ned, eliminere dem koldt og effektivt, ellers ville jeg ikke kunne stå mål med udfordringen.

"Stå mål med udfordringen", siger jeg, som om kommandantens sprog synker selv ind i mig. Men sådan er det vel? Man går hele tiden længere og længere, og bliver mere og mere indskrevet i begivenhederne. Døden er ikke længere noget, der foregår for os, vi bliver selv dens aktører, vi forlenes med den, den bliver vores eget sprog og vores egne replikker. Men så uskyldigt og rent er det menneskelige sind vel, at vi tror, at vi hver især skal ankomme til den, ad vores egne veje. Men det frygtelige er, at det er ens over hele linjen, det er sådan vores ankomst ser ud. Råb først en ordre ind i et menneskeligt ansigt med en dødelig trussel, og man bliver forrået. Og anden gang, så identificerer man sig restløst med denne ordre. Man bliver selv dødens egen aktør. Hvordan skulle jeg ellers, om tilfældet nu ville det, kunne møde denne kvinde der på gaden, der midt i sollyset, hvis hun kom i sin blå kittel? Hun ville spørge efter sine kunder, efter sin mand, efter sine voksne drenge? Hvad kunne jeg ellers andet end i en brøkdel af et sekund træde ind i kommandantens sprog og brysk støde hende tilbage på fortovet? Var det ikke det, han havde fortalt os, der ude i skoven, og som vi lyttede så andægtigt til mens vi så på de brændte døde? Og hvis vi så ikke sagde fra derude i Cambodia, havde vi så ikke også lovet ham det for sådan et øjeblik, at gå ind på hans løfter, kommandantens? At se på det sådan rent og koldt og effektivt, som noget, der skulle overståes uden "unødvendigt svineri"? Var vi ikke, to dage forinden, der allerede der om morgenen kunne synes så langt borte, blevet indskrevet i en sammensværgelse, som det ikke kunnelykkes for os at forråde? Var vi ikke allerede for sent på den?

Note: Vinter ved daggry udkommer hos Munksgaard/Rosinante til September. 